\title{
PORTAL HYPERTENSION TREATMENT WITH CANDESARTAN PLUS PROPRANOLOL FOR NINE MONTHS RESTORES NORMAL PORTAL CIRCULATION HEMODYNAMIC PATTERN By
}

\author{
MOHAMED D. ABD ALLA ${ }^{1 *}$, EL-SAYED M. M. EID ${ }^{1}$, ALI I. A. SOLIMAN ${ }^{1}$, \\ MOSTAFA A. ELHAWARY ${ }^{1}$, YASSER F. KILANY ${ }^{1}$, GADAH ABD-ALMONAEM ${ }^{2}$, \\ SAMEH S. BAYOUMI ${ }^{2}$, MOHAMED R. A. MOURSY ${ }^{3}$, FARES A. M. AL-ZAEM ${ }^{4}$ \\ Department of Tropical Medicine ${ }^{1}$, Faculty of Medicine, Al-Azhar University; Depart- \\ ment of Radiology ${ }^{2}$, Faculty of Medicine, Al-Zagazig University; Department of Clini- \\ cal Pathology ${ }^{3}$, Faculty of Medicine, Al-Azhar University and Department of Medicine, \\ Hepatology ICU Division ${ }^{4}$, Hhia Central Hospital \\ (Correspondence: Email: darwish011012@gmail.com; Phone: +2-0109-417-5209)
}

\section{Abstract}

Post HCV liver cirrhosis is one of the most prominent etiologies behind the abnormal portal circulation hemodynamics. It occurs as a result of distorted balance between portal venous flow (PVF) and intrahepatic resistances (IHR). PVF is partially controlled by using both specific and non-specific beta blockers (NSBBs) that have insignificant effects on IHR. Angiotensin receptor blockers (ARBs) inhibit the activated hepatic stellate cell (HSC) contraction and thought to reduce the dynamic portion of IHR. The study aimed to slow down the venous blood flow and to reduce the IHR of portal vein vasculature to control sequelae of the enhanced post cirrhosis portal venous turbulence. We evaluated the effects of Candesartan plus propranolol compared to each of them individually in management of portal hypertension $(\mathrm{PH})$. Three groups of 25 patients each, presented with chronic HCV infection and grade II- III esophageal varices (OV), were randomly assigned to one of three treatment regimens: Propranolol or Candesartan or both. Subjects were screened every three month by Doppler Ultrasound for a total of nine months. Damping Index (DI), pulse Pulsatility Index (PI), Portal Venous Flow (PVF) Volume, Portal Venous Peak Velocity (PVPV), and Portal Vein Diameter (PVD) were evaluated once every third month. Our study concluded that combined therapy (Propranolol + Candesartan) induced highly significant improvements that led to restoration of normal values of DI, PI, PVF volume \& PVPV overtime compared to monotherapy regimens $(\mathrm{P}>0.001)$. Data strongly recommended using Propranolol plus Candesartan in overtime management of portal hypertension.

Key Wards: Portal-vein, hemodynamics, NSBBs, ARBs, Combined therapy.

\section{Introduction}

Portal circulation hemodynamic status presents the outcome of interaction between the IHR with the amount of portal venous flow. Low cardiac output and splanchnic vasoconstriction are induced by selective and nonselective beta blockers (NSBB); each of them is associated with reduction in portal venous pressure. Success rate of NSBB in controlling $\mathrm{PH}$ by decreasing portal venous flow doesn't exceed 60\% (Feu et al, 1995). Reduction of portal blood flow only cannot satisfy the clinical needs that demand the conjoint development of new medical approaches to deal with reduction in IHR. The side effects and the insufficient reduction in portal pressure that are produced by NSBBs limit their use in medical managements of portal hypertension $(\mathrm{PH})$ and subsequently the esophageal varices (OV). In many patients with cirrhosis, the renin-angiotensin aldosterone (RAA) system is activated and has been involved in the pathogenesis of $\mathrm{PH}$ through liver fibrogenesis (Ballet et al, 1988; Kim et al, 2012). High levels of angiotensin II accelerate production of extracellular matrix and activate hepatic stellated cells (HSCs) that contract and induce an increased IHR (Bataller et al, 2000; Friedman 2000). Losartan was found to lower the portal pressure within 1 week in both severe and moderate PH (Schneider et al, 1999). 
However, these results failed to be reproduced by other investigators even after 6 weeks of treatment with losartan in comparison to propranolol (Gonzalez and Abraldes, et al, 2001). Candesartan is an Angiotensin II type-1 receptor (AT1-R) blocker that was approved for the treatment of arterial hypertension. It has a more potent in vitro blocking activity than Losartan (Verheijen, et al, 2002). So, it is expected that AT1-R blockers (ARB) to present a new medical approach in the management of portal hypertension by down regulation of IHR (Turnes, et al, 2006). The use of AT1-R blockers alone had the same or even less effect than NSBB that was demonstrated in previous cross-sectional studies (Schneider et al, 1999; Friedman et al, 2000; De et al, 2003; Yokohama et al, 2004). Predictors of portal circulation hemodynamic changes (DI, PI, PVF volume, PVPV, and PVD) are valuable tools that identify sequelae of $\mathrm{PH}$ in hepatic cirrhosis (Ozaki et al, 1988; Dauzat et al, 1990; Kim et al, 2007; Robinson et al, 2009; Swart and Sheth 2007; Moriyasu et al, 1986; Weinreb et al, 1982). PH itself is a major prognostic factor for these patients (Kim et $a l, 2009 ; 2011 ; 2012)$. Hepatic venous pressure gradient (HVPG) elevation to more than $10 \mathrm{mmHg}$ was associated with $\mathrm{PH}$ risky complications (D'Amico et al, 1999; Hong et al, 2013), mainly variceal bleeding that leads to $25 \%$ mortality rate (D'Amico et al, 2001; Kim et al, 2013).

The goal of current work was overtime evaluation of synergistic effects of Candesartan and Propranolol, compared to the monotherapy with each of them individually in controlling and reversing the portal circulation hemodynamic sequelae in post $\mathrm{HCV}$ cirrhotic patients.

\section{Subjects, Materials and Methods}

Seventy five patients, between $23 \& 61$ years of age, who had chronic liver disease and attended Al-Hussein, Sayed Galal and Zagazig University Hospital Outpatient Clinics between January 2014 \& August 2015 were included. All selected patients had chronic HCV infection diagnosed by serum HCV real time PCR. Patients were submitted to esophagogastroduodenoscopic screening, just before inclusion, and all had grade II-III esophageal varices (OV). All patients tested negative for serum antiSchistosomal IgG antibody with negative history of exposure to Nile river in last five years. Patients who had severe hepatic failure (serum bilirubin level $>5 \mathrm{mg} / \mathrm{dL}$ or hepatic encephalopathy), thrombosis in the hepatic or portal vein or inferior vena cava, hepatocellular carcinoma, uncontrolled infectious conditions (such as spontaneous bacterial peritonitis or sepsis), heart failure, acute renal failure or chronic renal failure (eGFR $<30 \mathrm{~mL} / \mathrm{min} / 1.73 \mathrm{~m}^{2}$ ), uncontrolled systemic hypertension, pregnancy or lactation, or did not provide informed consent were considered to be unsuitable candidates for current study and were excluded. The selected 75 patients were randomly signed, each to one of the three groups. Twenty five patients consisted each of three groups: GI) Propranolol GII) Candesartan GIII) Propranolol plus Candesartan (Combined). All patients received signed medicine and followed up every three month by Doppler ultrasound for nine months. Candesartan was administered at fixed small dose of $4 \mathrm{mg}$ twice daily (a total of $8 m g$ daily).

Propranolol was initially administered at small dose of $20 \mathrm{mg}$ daily and gradually increased till the targeted pulse and/or blood pressure are reached within two weeks. Propranolol dose was changed by addition of $10 \mathrm{mg}$ every third day to a maximum dose of $160 \mathrm{mg}$. The goal was to reach $25 \%$ reduction in heart rate from baseline or a 55 beats per minute to minimal heart rate for both combination and monotherapy groups. Propranolol dose was gradually reduced to the appropriate level in cases of patient intolerance, having less than 55 beats of heart rate/minute, or dropping systolic blood pressure to less than $90 \mathrm{mmHg}$. In case of persistent abnormal response despite of dose reduction, the drug was discontinued, patient 
was dropped from the study, and a replacement was introduced. All subjects adapted well the daily administration of $8 m g$ Candesartan plus 40mg Propranolol over the nine months follow-up.

Serum HCV Real Time PCR: The realtime PCR was carried out after a reverse transcription step. RNA was extracted from $200 \mu l$ of serum with the QIAamp Viral RNA kit (Qiagen), eluted in $60 \mu 1$ and stored at $-80^{\circ} \mathrm{C}$. RNA $(4 \mu \mathrm{l})$ was incubated with 1 pmol of a $\mathrm{HCV} 5^{\prime} \mathrm{NC}$ (non-coding) primer RC 21 for $8 \mathrm{~min}$ at $70^{\circ} \mathrm{C} \& 5 \mathrm{~min}$ at $4{ }^{\circ} \mathrm{C}$. RNA template was then reverse transcribed at $60^{\circ} \mathrm{C}$ for $1 \mathrm{~h}$ with $7.5 \mathrm{U}$ of Thermoscript $^{\mathrm{TM}}$ Reverse Transcriptase, $20 \mathrm{U}$ of RnaseOut, 10mM DTT, $1 \mathrm{mM}$ deoxyribonucleotide and cDNA buffer $(50 \mathrm{mM}$ Tris acetate $(\mathrm{pH} 8.4), 75 \mathrm{mM}$ potassium acetate, $8 \mathrm{mM}$ magnesium acetate) (GibcoBRL Life Technologies) in a final volume of $10 \mu l$. A denaturating step was performed at $95^{\circ} \mathrm{C}$ for $5 \mathrm{~min}$ and was followed by a RNase $\mathrm{H}$ treatment with $1 \mathrm{U}$ of $E$. coli RNase $\mathrm{H}$ (GibcoBRL Life Technologies) at $37^{\circ} \mathrm{C}$ for 20 min. cDNA was stored at $-20^{\circ} \mathrm{C}$.

The primers RC1 5'-GTC TAG CCA TGG CGT TAG TA-3' \& RC 21 5'-CTC CCG GGG CAC TCG CAA GC-3' (Clossais-Bernard and Andre, 1994) were designed to amplify a $220 \mathrm{bp}$ fragment within $5^{\prime}$ noncoding region of the $\mathrm{HCV}$ genome. These primers match the well conserved HCV sequences among the different genotypes, but did not match human frequent nucleic acid sequences according to PC-Rare software. The 3' octamers of RC1 \& RC21 occur less than once in $5 \times 10^{5} \& 4 \times 10^{6}$ bases of human genome respectively (Griffais et al, 1991). Real-time PCR was carried out with the LC DNA Master SYBR Green I kit (Roche Diagnostics) in a $20 \mu l$ reaction volume and was monitored after each elongation step, by SYBR Green I dye binding to amplified products using the LightCycler ${ }^{\mathrm{TM}}$ apparatus (Roche Diagnostics). The $220 \mathrm{bp}$ fragment was amplified from $2 \mu l$ of cDNA with 5 pmol of RC1 and RC21. Prior to amplifica- tion, the reaction mix was treated with $1 \mathrm{U}$ of uracil-DNA Glycosylase (Roche Diagnostics) to prevent DNA contamination (Longo et al., 1990), and with $0.2 \mu g$ of TaqStart ${ }^{\mathrm{TM}}$ Antibody (Clontech) to carry out a hot start PCR. An optimal $\mathrm{MgCl} 2$ concentration of $3 \mathrm{mM}$ was determined to obtain a specific and efficient amplification. The PCR protocol consisted in an initial denaturation step at $95^{\circ} \mathrm{C}$ for $120 \mathrm{~s}$, followed by 45 cycles of denaturation $\left(95^{\circ} \mathrm{C}\right.$ for $\left.2 \mathrm{~s}\right)$, annealing $\left(60^{\circ} \mathrm{C}\right.$ for $\left.5 \mathrm{~s}\right)$ and extension $\left(72^{\circ} \mathrm{C}\right.$ for 15 $\mathrm{s})$. For each step, the temperature transition rate was $20^{\circ} \mathrm{C} / \mathrm{s}$.

Quantitation was carried out using an external standard curve. Standard RNA was synthesized by transcription in vitro from a modified HCV cDNA containing a 40bp deletion in $5^{\prime}(\mathrm{NC})$ region and cloned into pBluescript SK plasmid (Clossais and Andre 1994). Briefly, positive strand RNA was transcribed for $4 \mathrm{~h}$ at $37^{\circ} \mathrm{C}$ from $1 \mu \mathrm{g}$ of plasmid digested by EcoRI with T3 RiboMAX $^{\mathrm{TM}}$ Large Scale RNA Production System (Promega). A DNase I treatment was performed for $15 \mathrm{~min}$ at $37^{\circ} \mathrm{C}$. After phenolchloroform purification and ethanol precipitation, the 334 base RNA fragment was controlled by gel electrophoresis and quantified by OD 260 measurement. Synthetic RNA was tested for contaminating plasmid DNA by PCR without RT step. Standard curves were constructed from serial 10 fold dilutions of synthetic HCV RNA in lysis buffer (QIAamp Viral RNA kit, Qiagen) and extracted in a HCV negative serum. After real time PCR was completed, logarithmic values of fluorescence ( $y$ axis) for each dilution were plotted against cycle number ( $x$ axis) (Fig. 2a). A baseline was set just above the fluorescence background and a crossing point was determined with the amplification curves obtained during the initial exponential phase of amplification. There was a direct relationship between the cycle number corresponding to the crossing point and the $\log$ concentration of RNA molecules initially present in the RT-PCR reaction. An accu- 
rate measurement over a large range of copy numbers was obtained. The linearity was conserved with the serial dilutions of the synthetic HCV RNA standard ranging from 1 to more than 7 Log RNA copies corresponding to 3.57 to 9.57 Log RNA copies / $\mathrm{ml}$ after correction by the dilution factor. The PCR amplification efficiency was controlled by the slope of the standard curve. Under the conditions, 1 molecule of $\mathrm{HCV}$ standard RNA corresponding to $2.54 \mathrm{Log}$ RNA copies/ml was detected in 10/22 realtime RT-PCR reactions (45\%). Therefore, 2.54 Log RNA copies / $m l$ in serum could be detected with optimal RNA extraction and cDNA synthesis conditions.

Examination of the esophagus, stomach and duodenum was done for all patients using Olympus GIF $\times \mathrm{Q} 30$ endoscope. Esophageal varices $(\mathrm{OV})$ were graded (Dagradi et al. 1973) based on modification of (Thakeb et al, 1988). OV grading was performed:Grade (I): Small straight varices confined to the lower third of the esophagus; Grade (II): Moderate size clubbed varices, with welldefined areas of normal mucosa between them, forming several distinct vertical cords and confined to the lower half of the esophagus; Grade (III): Gross varices extending into the proximal half of the esophagus and are so large and tortuous that normal mucosa may not be visible in between unless the esophagus is fully distended with air; Grade (IV): Varices are like those of grade III but with dilated capillaries on top or haemocysts.

Duplex Doppler ultrasound of the portal venous system has been used for assessment of portal venous system as a noninvasive and effective technique for estimation of PV pressure. All patients were kept in a fasting state overnight before the procedure at our institution. They were examined in the supine position in the right upper quadrant during quiet respiration ( $\mathrm{Li}$ and Yang, 2005). The following main Doppler factors were always determined by the same equipment (Phillips IU 22) and by the same operator.
Assessment of portal vein patency and blood flow: PV anatomy was evaluated using B-mode imaging. It was identified by following the splenic vein to the right until its junction with the superior mesenteric vein. This technique avoided confusing the PV with bile duct or the inferior vena cava. However, when the PV was difficult to observe in the supine position, the patient was examined in the left lateral decubitus position (Dib et al, 2006).

Estimation of portal hemodynamic parameters: Portal vein diameter and crosssectional area: Perpendicular to the long axis of the vein, the cross-sectional area was calculated from the formula of an ellipse, $(A \times B) / 4 \times \prod$, where $A$ is the long axis of the vein and $B$ was the short axis of the vein. If they were equal, the cross-sectional area was calculated using the following formula: $r^{2} \times$ $\prod$, where $r$ was half the diameter of the vein. The measurement of each vessel was performed from the inner wall to the inner wall at the site of the Doppler examination.

Damping Index of HV waveform in cirrhosis: The ratio between minimum velocity $(\mathrm{cm} / \mathrm{sec})$ of downward HV and maximum velocity $(\mathrm{cm} / \mathrm{sec})$ of downward $\mathrm{HV}$, as determined by duplex-Doppler system: Damping index $=$ Minimum velocity of downward $\mathrm{HV} \div$ Maximum velocity of downward HV.

Portal Vein Flow Volume: The portal venous flow (PVF) was calculated by the simple rule: $\mathrm{PVF}=\mathrm{V}$ mean $\mathrm{x}$ Cross area $\mathrm{x} 60$ (In $\mathrm{ml} / \mathrm{min})=($ in $\mathrm{cm} / \mathrm{sec})($ in $\mathrm{cm} 2)$, Ozaki et al. (1988) reported $874 \pm 207 \mathrm{ml} / \mathrm{min}$ as an average portal venous flow (PVF) in normal population, while Dauzat et al. (1990) found it to be $825 \pm 245 \mathrm{ml} / \mathrm{min}$. Aoki et al. (1995) found blood flow volume significantly increased in portal and splenic vein in cirrhotic patients

Portal Vein Pulsatility Index (PVPI): PVPI was calculated by the equation: (maximum minimum)/maximum frequency shift (47). PVPI is significantly lower in patients with chronic liver disease and cirrhosis (48). Color duplex sonography can be used to differ- 
entiate the hepatofugal, stagnant and hepatopetal direction of flow. Stagnant portal flow is presented as no detectable flow, which may occur during a right heart failure. Hepatofugal portal flow can be identified by observation of reversed portal vein flow (PVF) in cirrhotics (Rector et al, 1988). The markedly increased PVPI can predict a right heart failure (Hu et al, 2003; Rengo et al, 1998). Transient stagnant and hepatofugal portal flow may occur in the case of severe right heart failure, mainly during the ventricular systole (Hu et al, 2003).

Portal vein flow velocity: The velocity of blood flow in PV was calculated from Doppler tracings. Normal velocity of the blood flow in the PV was $15-20 \mathrm{~cm} / \mathrm{s}$. Portal hypertension was associated with an increase in blood flow and congestion, but with a decrease in blood velocity in PV. Duplex Doppler ultrasound is used to show blood flow within both the PV with its main tributaries and abnormal collaterals of the portal venous system. Measurement of the $V_{\max }$ and the calculating $V_{\text {mean }}$ : The sample volume is positioned in the center of the vessel and the gate is adjusted to eliminate the background. The velocity measured is the maximum velocity $\left(V_{\max }\right)$. The mean $V$ is calculated using the software as follows: $V$ peak obtained multiplied by a correction factor of $0.57 \mathrm{ob}-$ tained from an experimental study on a circulation mode. Three measurements were obtained and the average was utilized.

Statistical analysis: Data were analyzed using Statistical Program for Social Science (SPSS) version 18.0. Quantitative data were expressed as mean \pm standard deviation (SD). Qualitative data were expressed as frequency and percentage. The following tests were used: Independent-samples t-test of significance was used when comparing between two means. One-way analysis of variance (ANOVA) was for more than two means. Post Hoc test was used for multiple comparisons between different variables. Chi-square $\left(\mathrm{X}^{2}\right)$ test to compare proportions between two qualitative parameters. Probability (P- value): $<0.05$ was considered significant. $<0.001$ was considered as highly significant and $>0.05$ was considered insignificant.

\section{Results}

The changes in Damping Index in each group during follow up (Tab. 1A) showed that Candesartan monotherapy failed to normalize damping index after 9 month despite the significant improvement overtime $(\mathrm{P}<0.05)$. Propranolol monotherapy normalized damping index after 6 month, but these encouraging changes continued to be just significant during the next 3 months ( $P$ 0.023 ). On the other hand, combined therapy regimen restored normal damping index within 6 month and continued to show a very highly significant improvement over the last 3 month of follow up $(\mathrm{P}<0.001)$. The overtime changes compared (Tab. 1B) in Damping Index among studied three regimens showed that after therapy for 3 month, none of the three regimens succeeded to bring damping index down to its normal values. Propranolol containing regimens were significantly improving Damping Index overtime compared to Candesartan monotherapy $(\mathrm{P}<0.001)$. At $6 \& 9$ month, combination therapy significantly restored normal damping index values more than propranolol monotherapy $(\mathrm{P}<0.001)$. The value of Damping Index that reflected (Fig. 1) normal portal blood pressure was $<0.6$. Over nine month, combination therapy succeeded to bring $>0.7$ value of damping index down to $<0.5, \mathrm{P}<0.001$ compared to monotherapy with either propranolol or Candesar$\tan$ monotherapy. The wave pattern of DI in reference normal control (Tab. 6A; Fig. 6A.1a) compared to the therapeutic regimens at both baseline and at the $9^{\text {th }}$ month of follow up was recorded. The restoration of normal DI wave pattern occurred after nine month administration of combined therapy (Propranolol \& Candesartan) regimen (Fig. 6A.1g) compared to base line (Fig. 6A.1f). After treatment for nine month, the same section in table $6 \mathrm{~A}$ demonstrated failure of monotherapy regimens propranolol (Fig 
6A.1c), and Candesartan (Fig. 6A.1e) to reverse DI wave pattern changes seen at base line given (Fig. 6A.1b \& Fig, 6A.1d) respectively.

The changes in Pulse Plasticity Index (PI) in each group during follow up (Tab. 2A) demonstrated that PI showed significant increases toward normal values $(\geq 0.5)$ over time in each study group $(\mathrm{P}<0.001)$. None of monotherapy regimens succeeded to reach the normal value during the nine month follow-up. The combined therapy exceeded the bottom line of normal PI value during the $2^{\text {nd }}$ follow up, and continues to get significantly improved during the last 3 month $(\mathrm{P}<0.001)$. The overtime changes in PI (Tab. 2B) among three regimens declared that Propranolol containing regimens provided significant overtime improvements in PI compared to candesartan monotherapy during whole follow up period $(\mathrm{P}<0.03)$. Combination therapy regimen significantly improved PI during both $2^{\text {nd }} \& 3^{\text {rd }}$ follow up compared to propranolol monotherapy regimen $(\mathrm{P}<0.005)$. The overtime changes in PI upon using each of the three therapeutic regimens was illustrated (Fig. 2). The figure clarified that Propranolol + Candesartan therapeutic regimen succeeded to normalize PI hemodynamic value $(\geq 0.5 \mathrm{~cm} / \mathrm{sec})$ within 6 month of treatment compared to monotherapy ( $\mathrm{P}<0.005)$. PI continued to have significant improvement over the last 3 month of follow upon using combination therapy compared to either Propranolol or Candesartan monotherapy regimens ( $\mathrm{P}$ $<0.001)$. The wave pattern of PI in reference normal control was given (Tab. 6A) and compared to the studied therapeutic regimens at both baseline and at $9^{\text {th }}$ month follow up (Fig. 6A.2a). The restoration of normal PI wave patterns occurred after nine month administration of both propranolol monotherapy and combined therapy (Propranolol plus Candesartan) regimens (Fig. 6A.2c; 6A.2g) compared to base line (Fig. 6A.2b; 6A. 2f). After treatment for nine month, the same section in table 6A demon- strated failure of monotherapy Candesartan regimen (Fig 6A.2e) to reverse PI wave pattern changes seen at base line (Fig. 6A.2d).

The changes in PVF volume in each group (Tab. 3A) during follow up. All therapy regimens had significant decline in PVF volume over time during follow up compared to baseline $(\mathrm{P}<0.001)$. Candesartan monotherapy did not bring the PVF volume to any of its proposed normal vales at any time during follow up. Propranolol monotherapy as well as combination therapy (propranolol plus Candesartan) succeeded to normalize PVF after nine month $(\mathrm{P}<0.001)$. The changes in PVF volume among three therapeutic regimens were given (Tab. 3B). The PVF volume showed insignificant difference at baseline in all study groups $(\mathrm{P}>0.5)$. Also, both combination therapy and Propranolol monotherapy had significant reduction in PVF volume compared to Candesartan monotherapy $(\mathrm{P}<0.05)$ over the three follow-ups. There was non-significant overtime change in PVF on comparing combination therapy regimen with Propranolol monotherapy $(\mathrm{P}$ $>0.05$ ). Simply the overtime changes in PVF volume in groups, PVF volume showed (Fig. 3) significant improvement overtime on using propranolol containing regimens compared to candesartan monotherapy (P $>0.05)$. After nine month, at the end of follow up, combined therapy (Propranolol +Candesartan) induced more significant improvement in PVF compared to propranolol monotherapy $(\mathrm{P}=0.005)$. The wave pattern of PVF volume (Tab. 6B) in reference normal control (Fig. 6B) compared to the studied therapeutic regimens at both baseline and at $t 9^{\text {th }}$ month of follow up. The restoration of normal PVFV wave pattern was accomplished after nine month administration of combined therapy regimens compared to base line (Fig. 6B. 1g,1f). After treatment for nine month, the same section (Tab. 6B) showed failure of monotherapy Candesartan regimen (Fig 6B.1e) to reverse PVF volume wave pattern and values changes seen at base line (Fig. 6B.1d). On the other hand, 
Propranolol monotherapy succeeded to restore the normal value, but not the normal pattern, of PVF volume wave after nine month therapy (Fig. 6B. 1c, Id) compared to baseline.

The changes in PVPV in each group (Tab. 4A) during follow up, all therapy regimens induced significant improvements in portal venous peak velocity (PVPV) in each group during follow up compared to baseline ( $\mathrm{P}<$ 0.05). These changes became insignificant between the $3^{\text {rd }} \& 9^{\text {th }}$ month in monotherapy regimens $(\mathrm{P}>0.05)$. The combined therapy regimen continued to show significant improvements till the end of $6^{\text {th }}$ month $(\mathrm{P}<$ $0.005)$; these changes became insignificant between $6^{\text {th }} \& 9^{\text {th }}$ month $(\mathrm{P}=0.245)$. Table $4 B$ compared changes in PVPV among the studied three therapeutic regimens. At baseline, there was insignificant difference in PVPV among study groups $(\mathrm{P}>0.4)$. The same table showed that Propranolol had just significant improvement in PVPV compared to Candesartan $(\mathrm{P}=0.046)$ at first follow up. However, combination therapy regimen induced a highly significant increase in PVPV by end of the $2^{\text {nd }}$ follow up compared to monotherapy regimens $(\mathrm{P}<0.005)$. At end of 9 month, Propranolol containing regimens showed significantly improved PVPV compared to Candesartan monotherapy regimen $(\mathrm{P}<0.05)$. The overtime changes in PVPV in study groups (Fig. 4) showed that the combination therapy regimen induced a significant improvement in PVPV by the end of 6 month compared to monotherapy regimens $(\mathrm{P}<0.005)$. By the end of the 9 month, both Propranolol containing regimens showed significantly improved PVPV compared to Candesartan monotherapy regimen (P
$<0.005$ ). The wave pattern (Tab. 2) of PVPV in reference normal control (Fig. 6B.2a) compared to the studied therapeutic regimens at both baseline and at the $9^{\text {th }}$ month of follow up. There was restoration of normal PVPV wave patterns, but not wave values, after nine month administration of both Propranolol containing (mono \& combined) therapeutic regimens compared to base line (Fig. 6B. 2b 2c, 2g \& 2f). After treatment for nine month, the same section (Tab. 6B) demonstrated failure of monotherapy Candesartan regimen to reverse PVF volume wave pattern and value changes seen at base line.

The changes in PVD in each group (Tab. 5A) during follow up. All regimens showed significant reduction in PVD during $2^{\text {nd }}, \&$ $3^{\text {rd }}$ follow-ups compared to baseline ( $P$ $<0.02)$. Significant reduction was also noted on comparing $1^{\text {st }} \& 3^{\text {rd }}$ follow up only in combined therapy regimen $(\mathrm{P}<0.005)$. None of the studied therapeutic regimens had significant changes on comparing the last two follow up with each other $(\mathrm{P}>0.4)$. Table $5 B$ compared changes in PVD among the studied three therapeutic regimens. No significant change was noted among study groups at both baseline \& $1^{\text {st }}$ follow up $(\mathrm{P}>0.1)$. Combination therapy showed close to significant reduction in PVD at the end of both 6th and 9th month follow up on comparison to Candesartan monotherapy ( $\mathrm{P}=0.06$ ). Propranolol monotherapy failed to make any considerable changes in PVD $(\mathrm{P}=0.194)$ and Candesartan monotherapy $(\mathrm{P}=0.062)$. None of the studied therapeutic regimens brought down PVD to its normal value ranges, despite improvement upon using combination regimen. 
Table 1A: Changes in Damping Index in each group during follow up

\begin{tabular}{|r|c|c|c|}
\hline & Group I: Propranolol & Group II: Candesartan & Group III: Combined \\
\hline Base line (day 1) & $0.75 \pm 0.06$ & $0.74 \pm 0.05$ & $0.73 \pm 0.06$ \\
\hline $1^{\text {st }}$ follow up (3 month) & $0.66 \pm 0.05$ & $0.70 \pm 0.04$ & $0.61 \pm 0.05$ \\
\hline $2^{\text {nd }}$ follow up (6 month) & $0.57 \pm 0.03$ & $0.65 \pm 0.03$ & $0.53 \pm 0.04$ \\
\hline $3^{\text {rd }}$ follow up (9month) & $0.53 \pm 0.03$ & $0.60 \pm 0.04$ & $0.49 \pm 0.03$ \\
\hline P value: BL vs $1^{\text {st }} \mathrm{FU}$ & $<0.001^{* *}$ & $0.003^{*}$ & $<0.001^{* *}$ \\
BL vs 2 & $<0.001^{* *}$ \\
BL vs $3^{\text {rd }} \mathrm{FU}$ & $<0.001^{* *}$ & $<0.001^{* *}$ & $<0.001^{* *}$ \\
$1^{\text {st }}$ vs 2 $2^{\text {nd }} \mathrm{FU}$ & $<0.001^{* *}$ & $<0.001^{* *}$ & $<0.001^{* *}$ \\
$1^{\text {st }}$ vs 3d $\mathrm{FU}$ & $<0.001^{* *}$ & $0.008^{*}$ & $<0.001^{* *}$ \\
$2^{\text {nd }}$ vs $3^{\text {rd }} \mathrm{FU}$ & $<0.001^{* *}$ & $<0.001^{* *}$ & $<0.001^{* *}$ \\
\hline
\end{tabular}

Candesartan monotherapy failed to normalize damping index after 9 month despite significant changes overtime $(\mathrm{P}<$ 0.05). Propranolol monotherapy normalized damping index after 6 month, but these changes continued to be just significant during next 3 months (P 0.023). Combined therapy restored normal damping index within 6 month and continued to show a very highly significant drop over the next 3 month $(\mathrm{P}<0.001)$

Table 1B: Comparison of Overtime Changes in Damping Index among Study Regimens

\begin{tabular}{|r|c|c|c|c|}
\hline & Base line (day 1) & $1^{\text {st }}$ follow up & $2^{\text {nd }}$ follow up & $3^{\text {rd }}$ follow up \\
\hline GI: Propranolol & $0.75 \pm 0.06$ & $0.66 \pm 0.05$ & $0.57 \pm 0.03$ & $0.55 \pm 0.03$ \\
\hline GII: Candesartan & $0.74 \pm 0.05$ & $0.70 \pm 0.04$ & $0.65 \pm 0.03$ & $0.60 \pm 0.04$ \\
\hline GIII: Combined & $0.73 \pm 0.06$ & $0.61 \pm 0.05$ & $0.53 \pm 0.04$ & $0.49 \pm 0.03$ \\
\hline P value: I vs II & 0.525 & $<0.001 * *$ & $<0.001 * *$ & $<0.001^{* *}$ \\
I vs III & 0.244 & $<0.001^{* *}$ & $<0.001^{* *}$ & $<0.001^{* *}$ \\
II vs III & 0.525 & $<0.001 * *$ & $<0.001^{* *}$ & $<0.001 * *$ \\
\hline
\end{tabular}

After therapy for 3 month, none of three regimens succeeded to bring damping index down to its normal values. Propranolol containing regimens significantly improving Damping Index overtime compared to Candesartan monotherapy (P < 0.001). At 6 \& 9 month, combination therapy significantly restored normal damping index values more than propranolol monotherapy $(\mathrm{P}<0.001)$.

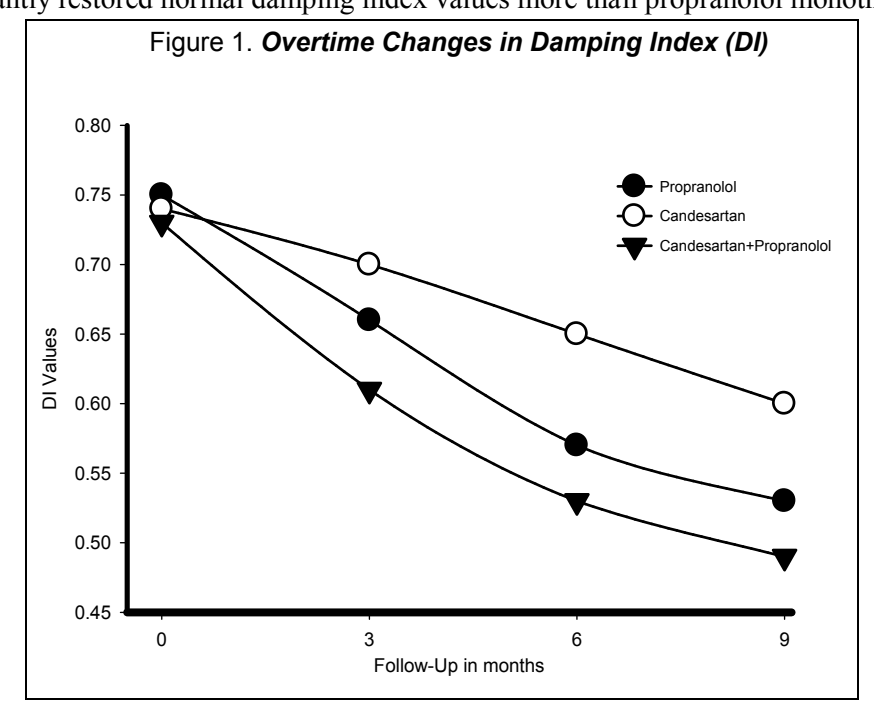

Fig. 1: Damping index values reflect normal portal blood pressure $<0.6$. Over 9 month, combination therapy succeeded to $>0.7$ value of damping index down to $<0.5, \mathrm{P}<$ 0.001 compared to monotherapy with either propranolol or Candesartan.

\begin{tabular}{|c|c|c|c|}
\hline & GI: Propranolol & GII: Candesartan & GIII: Combined \\
\hline Base line (day 1) & $0.32 \pm 0.068$ & $0.31 \pm 0.071$ & $0.30 \pm 0.069$ \\
\hline $1^{\text {st }}$ follow up (3 month) & $0.37 \pm 0.062$ & $0.319 \pm 0.057$ & $0.39 \pm 0.056$ \\
\hline $2^{\text {nd }}$ follow up (6 month) & $0.45 \pm 0.048$ & $0.34 \pm 0.047$ & $0.5 \pm 0.042$ \\
\hline $3^{\text {rd }}$ follow up (9month) & $0.49 \pm 0.04$ & $0.44 \pm 0.038$ & $0.64 \pm 0.059$ \\
\hline P value: $\mathrm{BL}$ vs $1^{\text {st }} \mathrm{FU}$ & 0.330 & 0.623 & $<0.001$ \\
\hline $\mathrm{BL}$ vs $2^{\text {nd }} \mathrm{FU}$ & $<0.001$ & 0.085 & $<0.001$ \\
\hline $\mathrm{BL}$ vs $3^{\text {rd }} \mathrm{FU}$ & $<0.001$ & $<0.001$ & $<0.001$ \\
\hline $1^{\text {st }}$ vs $2^{\text {nd }} \mathrm{FU}$ & $<0.001$ & 0.162 & $<0.001$ \\
\hline $1^{\text {st }} \mathrm{vs} 3^{\text {rd }} \mathrm{FU}$ & $<0.001$ & $<0.001$ & $<0.001$ \\
\hline $2^{\text {nd }} \mathrm{vs} 3^{\text {rd }} \mathrm{FU}$ & 0.003 & $<0.001$ & $<0.001$ \\
\hline
\end{tabular}

PI significant increased to normal values $(\geq 0.5)$ over time in each study group $(\mathrm{P}<0.001)$. None of monotherapy regimens succeeded to normal value during nine month follow-up. Combined therapy exceeded bottom line of normal PI value during $2^{\text {nd }}$ follow up, and continues to get significantly improved 3 month $(\mathrm{P}<0.001)$. 
Table 2B: Comparing Overtime Changes in Pulse-Pulsatility Index (PI) among Study Regimens

\begin{tabular}{|r|c|c|c|c|}
\hline & Base line (day 1) & $1^{\text {st }}$ follow up & $2^{\text {nd }}$ follow up & $3^{\text {rd }}$ follow up \\
\hline GI: Propranolol & $0.32 \pm 0.068$ & $0.37 \pm 0.062$ & $0.45 \pm 0.048$ & $0.49 \pm 0.04$ \\
\hline GII: Candesartan & $0.31 \pm 0.071$ & $0.319 \pm 0.057$ & $0.34 \pm 0.047$ & $0.44 \pm 0.038$ \\
\hline GIII: Combined & $0.30 \pm 0.069$ & $0.39 \pm 0.056$ & $0.5 \pm 0.042$ & $0.64 \pm 0.059$ \\
\hline P value: I vs II & 0.380 & 0.004 & 0.001 & $<0.001$ \\
I vs III & 0.100 & 0.237 & 0.003 & $<0.001$ \\
II vs III & 0.616 & 0.021 & 0.001 & $<0.001$ \\
\hline
\end{tabular}

Propranolol containing regimens showed significant overtime improvements in PI compared to candesartan monotherapy during all follow up period $(\mathrm{P}<0.03)$. Combination therapy regimen significantly improved PI during both $2^{\text {nd }} \& 3^{\text {rd }}$ follow up compared to propranolol monotherapy $(\mathrm{P}<0.005)$.

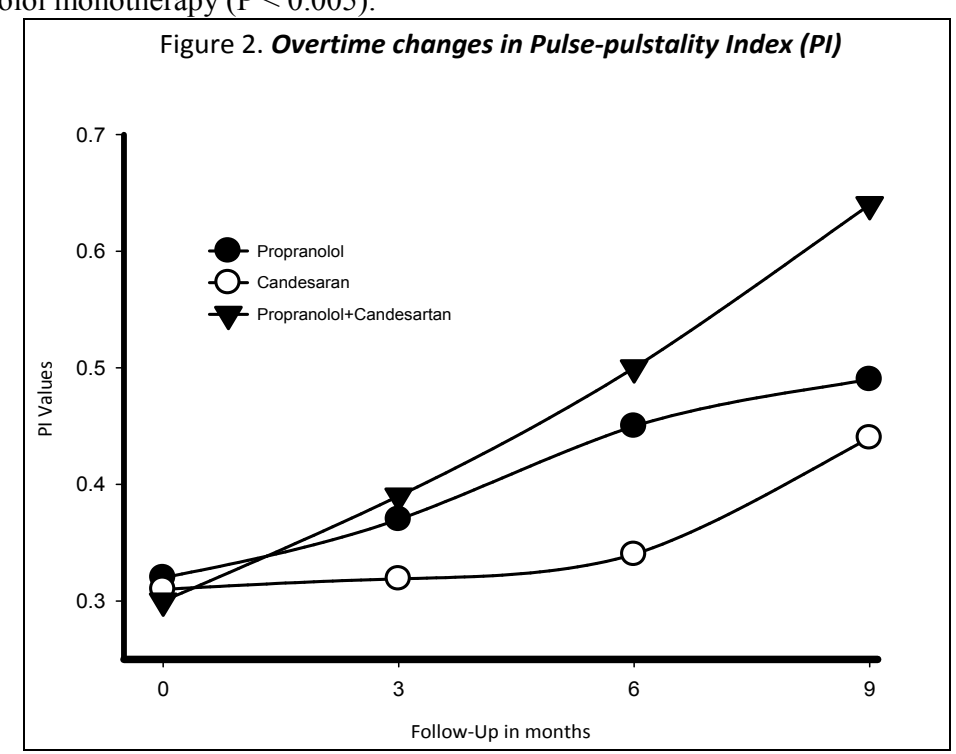

Propranolol + Candesartan therapeutic regimen normalizes PI value $(>0.5)$ within 6 month. PI continued to significantly improving over last 3 month of follow upon using combination therapy compared to either Propranolol or Candesartan monotherapy regimens $(\mathrm{P}<0.001)$.

Table 3A: Changes in portal venous flow (PVF) volume in each group during follow up

\begin{tabular}{|r|c|c|c|}
\hline & G I:Propranolol & G II: Candesartan & GIII: Combined \\
\hline Base line (day 1) & $1159.6 \pm 135.2$ & $1136.1 \pm 131.6$ & $1214 \pm 133.4$ \\
\hline $1^{\text {st }}$ follow up (3 month). & $984.4 \pm 109.9$ & $1113.6 \pm 122.2$ & $1063 \pm 96$ \\
\hline $2^{\text {nd }}$ follow up (6 month) & $898.3 \pm 58.7$ & $1007.3 \pm 84.5$ & $925.3 \pm 97.7$ \\
\hline $3^{\text {rd }}$ follow up (9month) & $801.1 \pm 36.5$ & $892.3 \pm 53.1$ & $765.5 \pm 47.2$ \\
\hline P value: BL vs $1^{\text {st }} \mathrm{FU}$ & $<0.001$ & $<0.001$ & $<0.001$ \\
BL vs. $2^{\text {nd }} \mathrm{FU}$ & $<0.001$ & $<0.001$ & $<0.001$ \\
BL vs. $3^{\text {rd }} \mathrm{FU}$ & $<0.001$ & 0.004 & $<0.001$ \\
$1^{\text {st }}$ vs. $2^{\text {nd }} \mathrm{FU}$ & 0.002 & $<0.001$ & $<0.001$ \\
$1^{\text {st }}$ vs. $3^{\text {rd }} \mathrm{FU}$ & $<0.001$ & $<0.001$ & $<0.001$ \\
$2^{\text {nd }}$ vs. $3^{\text {rd }} \mathrm{FU}$ & $<0.001$ & & \\
\hline
\end{tabular}

All therapy regimens showed significant decline in PVF volume over time during follow up compared to baseline (P $<0.001)$. Candesartan monotherapy failed to bring PVF to any of its proposed normal vales at any time in follow up. Propranolol monotherapy as well as combination therapy (propranolol plus Candesartan) succeeded to normalize PVF after 9 month $(\mathrm{P}<0.001)$.

Table3B: Comparing overtime changes in portal venous flow (PVF) volume among study regimens

\begin{tabular}{|r|c|c|c|c|}
\hline & Base line & $1^{\text {st }}$ follow up & $2^{\text {nd }}$ follow up & $3^{\text {rd }}$ follow up \\
\hline GI: Propranolol & $1159.6 \pm 135.2$ & $984.4 \pm 109.9$ & $898.3 \pm 58.7$ & $801.1 \pm 36.5$ \\
\hline GII: Candesartan & $1136.1 \pm 131.6$ & $1113.6 \pm 122.2$ & $1007.3 \pm 84.5$ & $892.3 \pm 53.1$ \\
\hline G III: Combined & $1214 \pm 133.4$ & $1063 \pm 96$ & $925.3 \pm 97.7$ & $765.5 \pm 47.2$ \\
\hline P Value: I vs II & 0.536 & 0.003 & $<0.001$ & 0.242 \\
I vs III & 0.159 & 0.010 & 0.003 & 0.005 \\
II vs III & 0.053 & $<0.001$ & $<0.001$ & 0.001 \\
\hline
\end{tabular}

At baseline, no difference in PVF volume among groups. Overtime, both combination therapy and Propranolol monotherapy showed significant reduction in PVF compared to Candesartan monotherapy $(\mathrm{P}<0.05)$, non-significant overtime change in PVF on comparing combination therapy with Propranolol monotherapy $(\mathrm{P}>0.05)$. 


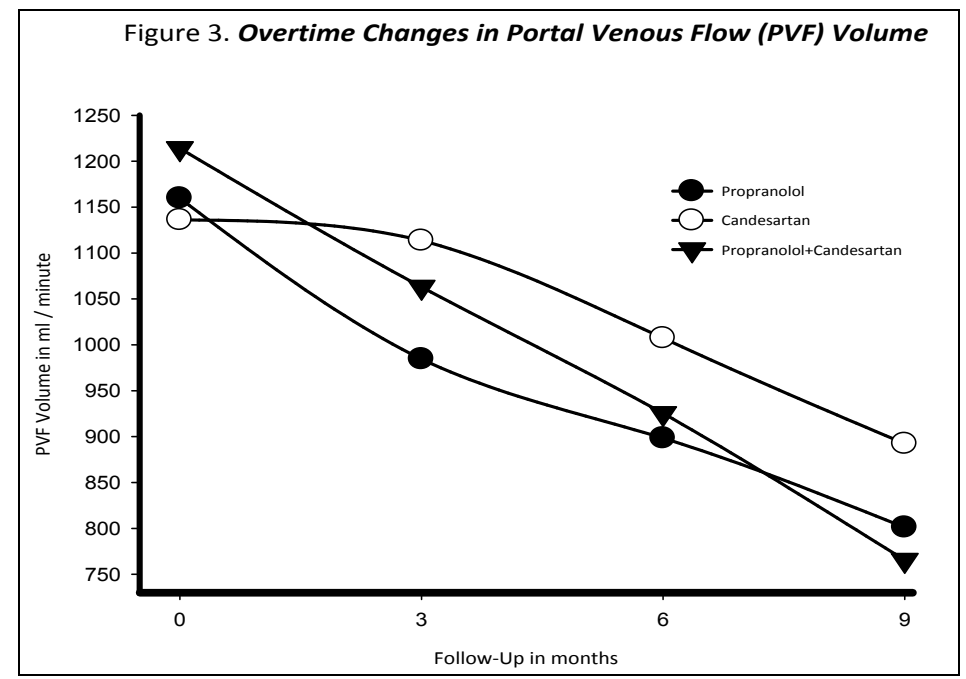

Fig. 3: PVF showed significant improvement overtime with propranolol compared to candesartan monotherapy $(\mathrm{P}>0.05)$, nine month, combined therapy induced significant improvement in $\mathrm{PVF}$ compared to propranolol $(\mathrm{P}=0.005)$

Table 4A: Changes in portal venous peak velocity (PVPV) in each group during follow up

\begin{tabular}{|r|c|c|c|}
\hline & G I: Propranolol & G II: Candesartan & GIII: Combined \\
\hline Base line (day 1) & $10.68 \pm 2.06$ & $11.20 \pm 2.43$ & $11.08 \pm 2.02$ \\
\hline $1^{\text {st }}$ follow up(3 month) & $11.70 \pm 1.43$ & $12.59 \pm 1.50$ & $12.33 \pm 1.49$ \\
\hline $2^{\text {nd }}$ follow up(6 month) & $12.26 \pm 1.60$ & $12.82 \pm 1.24$ & $13.84 \pm 0.83$ \\
\hline $3^{\text {rd }}$ follow up(9month) & $13.91 \pm 1.01$ & $13.07 \pm 1.08$ & $14.10 \pm 0.73$ \\
\hline P value: BL vs $1^{\text {st }} \mathrm{FU}$ & 0.048 & 0.019 & 0.016 \\
BL vs. ${ }^{\text {nd }} \mathrm{FU}$ & 0.004 & 0.005 & 0.003 \\
BL vs. $3^{\text {rd }} \mathrm{FU}$ & 0.002 & 0.002 & 0.002 \\
$1^{\text {st }}$ vs. $2^{\text {nd }} \mathrm{FU}$ & 0.201 & 0.557 & 0.002 \\
$1^{\text {st }}$ vs. $3^{\text {rd }} \mathrm{FU}$ & 0.065 & 0.203 & $<0.001$ \\
$2^{\text {nd }}$ vs. $3^{\text {rd }} \mathrm{FU}$ & 0.113 & 0.451 & 0.245 \\
\hline
\end{tabular}

All regimens showed significant improvements in PVPV overtime compared to baseline $(\mathrm{P}<0.05)$, without significant between $3^{\text {rd }} \& 9^{\text {th }}$ month in monotherapy $(P>0.05)$. Combined therapy regimen continued significant improvements to $6^{\text {th }}$ month $(\mathrm{P}<0.005)$, without significant between $6^{\text {th }} \& 9^{\text {th }}$ month $(\mathrm{P}=0.245)$.

Table 4B: Comparing over time changes in Portal Venous Peak Velocity (PVPV) among study groups

\begin{tabular}{|r|c|c|c|c|}
\hline & Base line (day 1) & $1^{\text {st }}$ follow up & $2^{\text {nd }}$ follow up & $3^{\text {rd }}$ follow up \\
\hline G I Propranolol & $10.68 \pm 2.06$ & $11.70 \pm 1.43$ & $12.26 \pm 1.60$ & $13.91 \pm 1.01$ \\
\hline GII Candesartan & $11.20 \pm 2.43$ & $12.59 \pm 1.50$ & $12.82 \pm 1.24$ & $13.07 \pm 1.08$ \\
\hline GIII Both & $11.08 \pm 2.02$ & $12.33 \pm 1.49$ & $13.84 \pm 0.83$ & $14.10 \pm 0.73$ \\
\hline P Value: I vs, II & 0.401 & 0.0461 & 0.173 & 0.006 \\
I vs. III & 0.518 & 0.157 & 0.001 & 0.449 \\
II vs. III & 0.846 & 0.569 & 0.004 & 0.003 \\
\hline
\end{tabular}

Propranolol showed significant changes in PVPV compared to Candesartan $(\mathrm{P}=0.046)$ at $1^{\text {st }}$ follow up. Combination regimens induced a highly significant increase in PVPV by end of $2^{\text {nd }}$ follow up compared to monotherapy $(\mathrm{P}<0.005)$. At end of $9^{\text {th }}$ month, Propranolol containing regimens showed significantly improved compared to Candesartan $(\mathrm{P}<0.05)$.

Table 5A: Changes in means \pm standard deviation of Portal vein diameter during follow up in each group

\begin{tabular}{|r|c|c|c|}
\hline & G I: Propranolol & G II: Candesartan & G III: Combined \\
\hline Base line (day 1) & $15.24 \pm 0.72$ & $15.46 \pm 0.80$ & $15.30 \pm 0.80$ \\
\hline $1^{\text {st }}$ follow up (3 month) & $14.93 \pm 0.64$ & $15.23 \pm 0.77$ & $14.98 \pm 0.75$ \\
\hline $2^{\text {nd }}$ follow up(6 month) & $14.63 \pm 0.66$ & $14.97 \pm 0.60$ & $14.39 \pm 0.74$ \\
\hline $3^{\text {rd }}$ follow up(9month) & $14.51 \pm 0.61$ & $14.83 \pm 0.75$ & $14.23 \pm 0.60$ \\
\hline P value: BL vs $1^{\text {st }} \mathrm{FU}$ & 0.114 & 0.306 & 0.151 \\
BL vs. $2^{\text {nd }} \mathrm{FU}$ & 0.003 & 0.018 & 0.002 \\
BL vs. $3^{\text {rd }} \mathrm{FU}$ & 0.004 & 0.006 & 0.001 \\
$1^{\text {st }}$ vs. $2^{\text {nd }} \mathrm{FU}$ & 0.109 & 0.189 & 0.071 \\
$1^{\text {ts }}$ vs. $3^{\text {rd }} \mathrm{FU}$ & 0.022 & 0.069 & 0.004 \\
$2^{\text {nd }}$ vs. $3^{\text {rd }} \mathrm{FU}$ & 0.507 & 0.469 & 0.405 \\
\hline
\end{tabular}

Portal vein diameter showed significant reduction overtime in all regimens during $2^{\text {nd }} \& 3^{\text {rd }}$ follow up compared to baseline $(\mathrm{P}<0.02)$. Significant reduction on comparing $1^{\text {st }} \& 3^{\text {rd }}$ follow up in combined therapy $(\mathrm{P}<0.005)$, none of therapeutic regimens had significant changes on comparing the last two follow up with each other $(\mathrm{P}>0.4)$. 


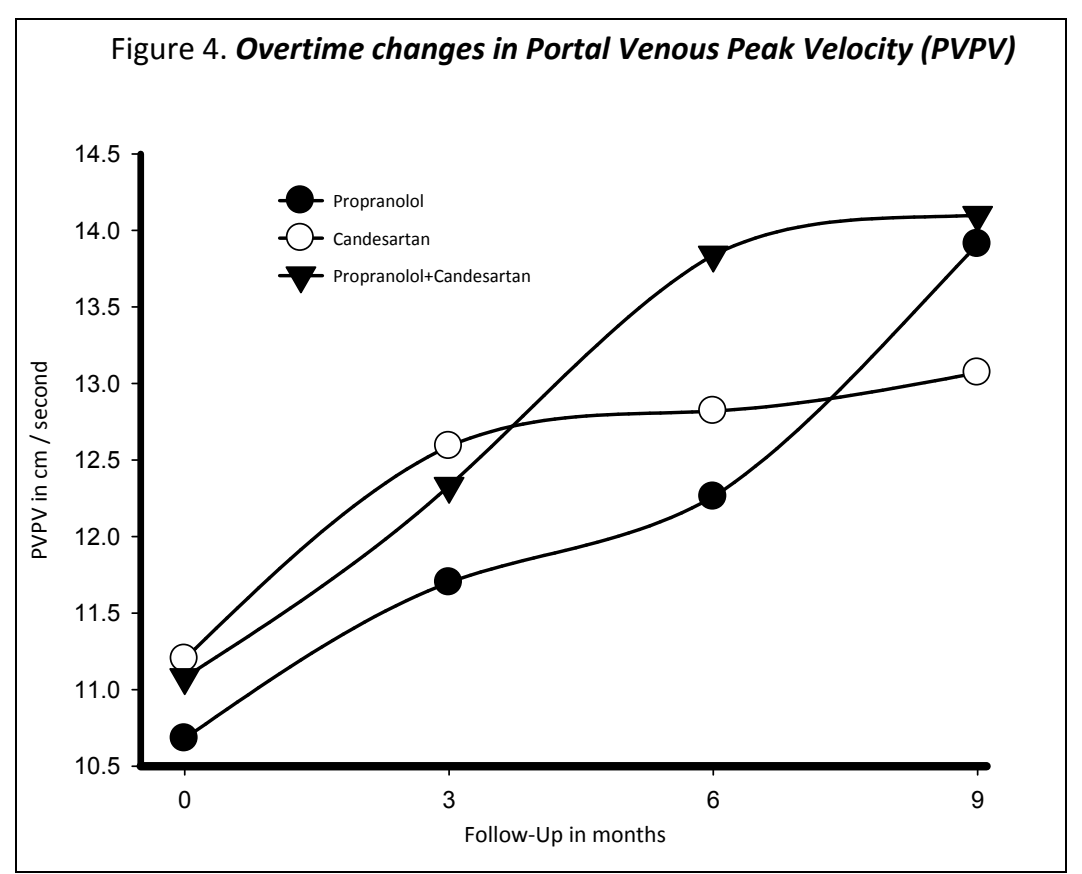

Fig. 4: Combination therapy induced a significant improvement to PVPV by end of 6 month compared to monotherapy $(\mathrm{P}<0.005)$. By end of 9 month, Propranolol containing regimens showed significantly improved PVPV compared to Candesartan $(\mathrm{P}<0.005)$.

Table 5B: Comparing overtime changes in means \pm standard deviation of portal vein diameter among all study groups

\begin{tabular}{|r|c|c|c|c|}
\hline & Base line (day 1) & $1^{\text {st }}$ follow up & $2^{\text {nd }}$ follow up & $3^{\text {rd }}$ follow up \\
\hline G I: Propranolol & $15.24 \pm 0.72$ & $14.93 \pm 0.64$ & $14.63 \pm 0.66$ & $14.51 \pm 0.61$ \\
\hline G II: Candesartan & $15.46 \pm 0.80$ & $15.23 \pm 0.77$ & $14.97 \pm 0.60$ & $14.83 \pm 0.75$ \\
\hline GIII: Combined & $15.30 \pm 0.80$ & $14.98 \pm 0.75$ & $14.39 \pm 0.74$ & $14.23 \pm 0.60$ \\
\hline P Value: I vs. II & 0.320 & 0.170 & 0.521 & 0.511 \\
I vs. III & 0.786 & 0.850 & 0.194 & 0.191 \\
II vs. III & 0.469 & 0.258 & 0.062 & 0.061 \\
\hline
\end{tabular}

Combination therapy showed significant reduction in portal vein diameter at end of $6^{\text {th }} \& 9^{\text {th }}$ month follow up on comparison to Candesartan $(\mathrm{P}=0.06)$, without significant change among groups at baseline $\& 1^{\text {st }}$ follow up $(\mathrm{P}>0.1)$. Propranolol failed to make changes in portal vein diameter compared to Candesartan at all follow up $(\mathrm{P}>0.1)$.

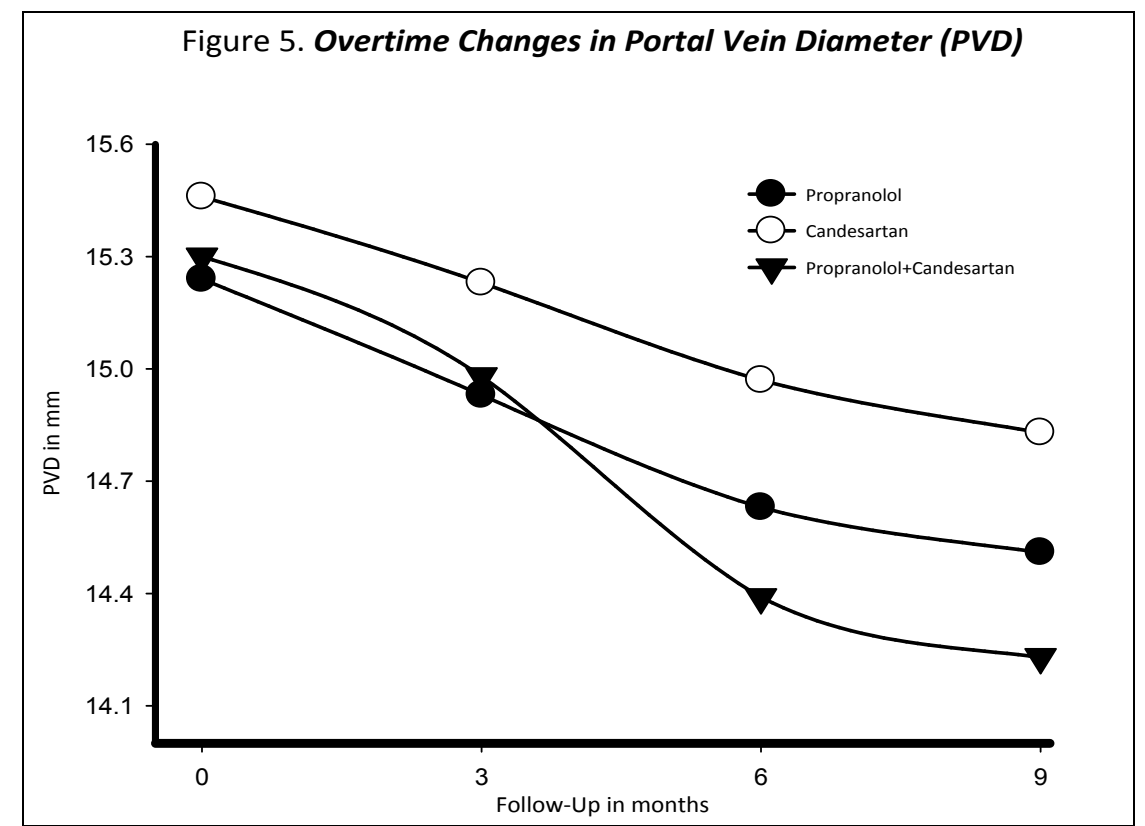

Fig. 5: Combined regimen produced reduction in portal vein diameter at six \& nine month follow compared to propranolol $(\mathrm{P}=0.194)$ and Candesartan $(\mathrm{P}=0.062)$. 


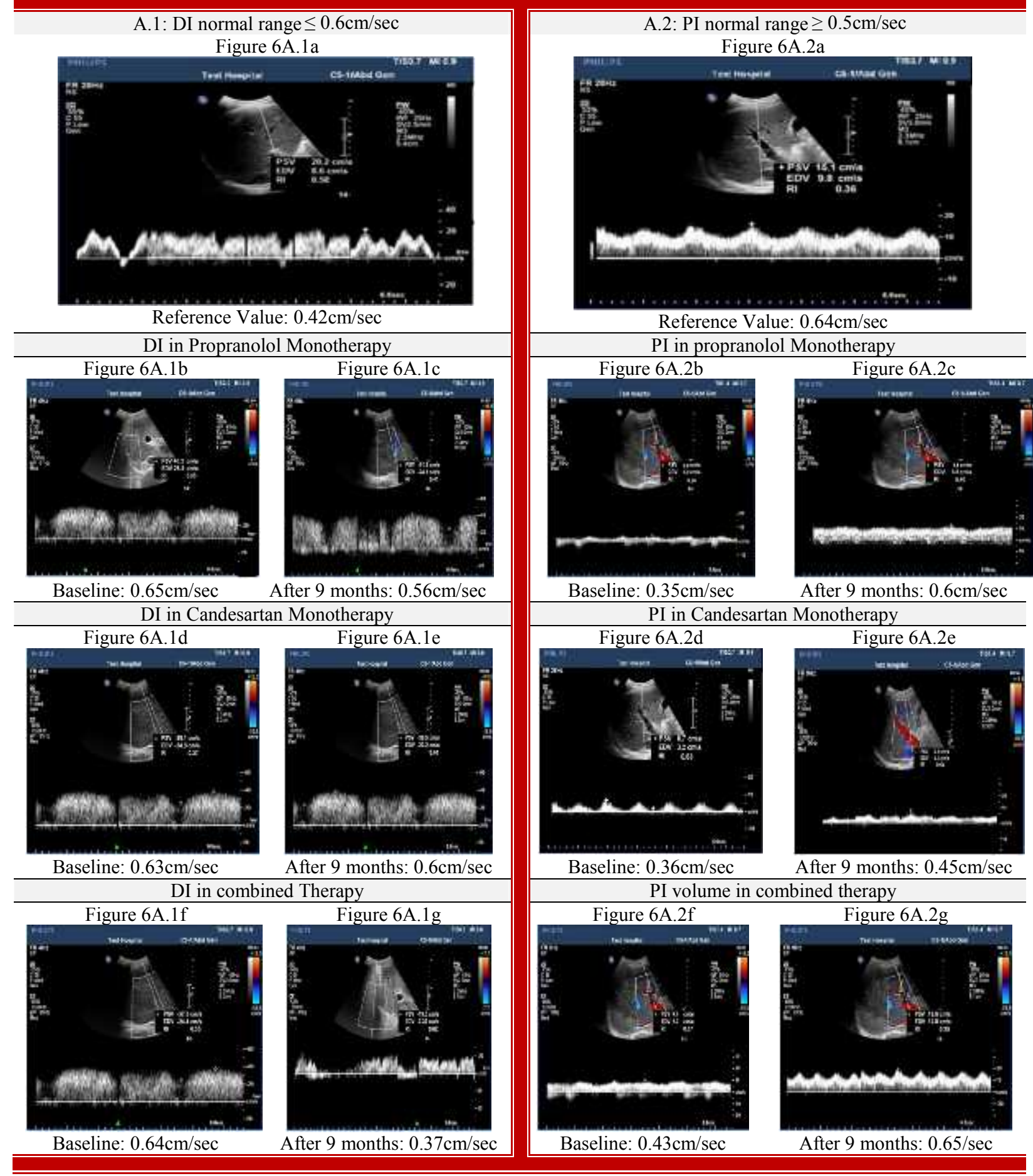

Restoration of DI \& PI normal waves patterns accomplished by combined therapy after administration for nine months. Propranolol succeeded to restore PI, but not DI, normal wave pattern at end of 9 month therapy. Candesartan monotherapy failed to restore normal pattern of DI \& PI at end of follow up. 
Table 6B: Portal vein flow (PVF) volume and Portal Vein Peak Velocity (PVPV) changes in all regimens

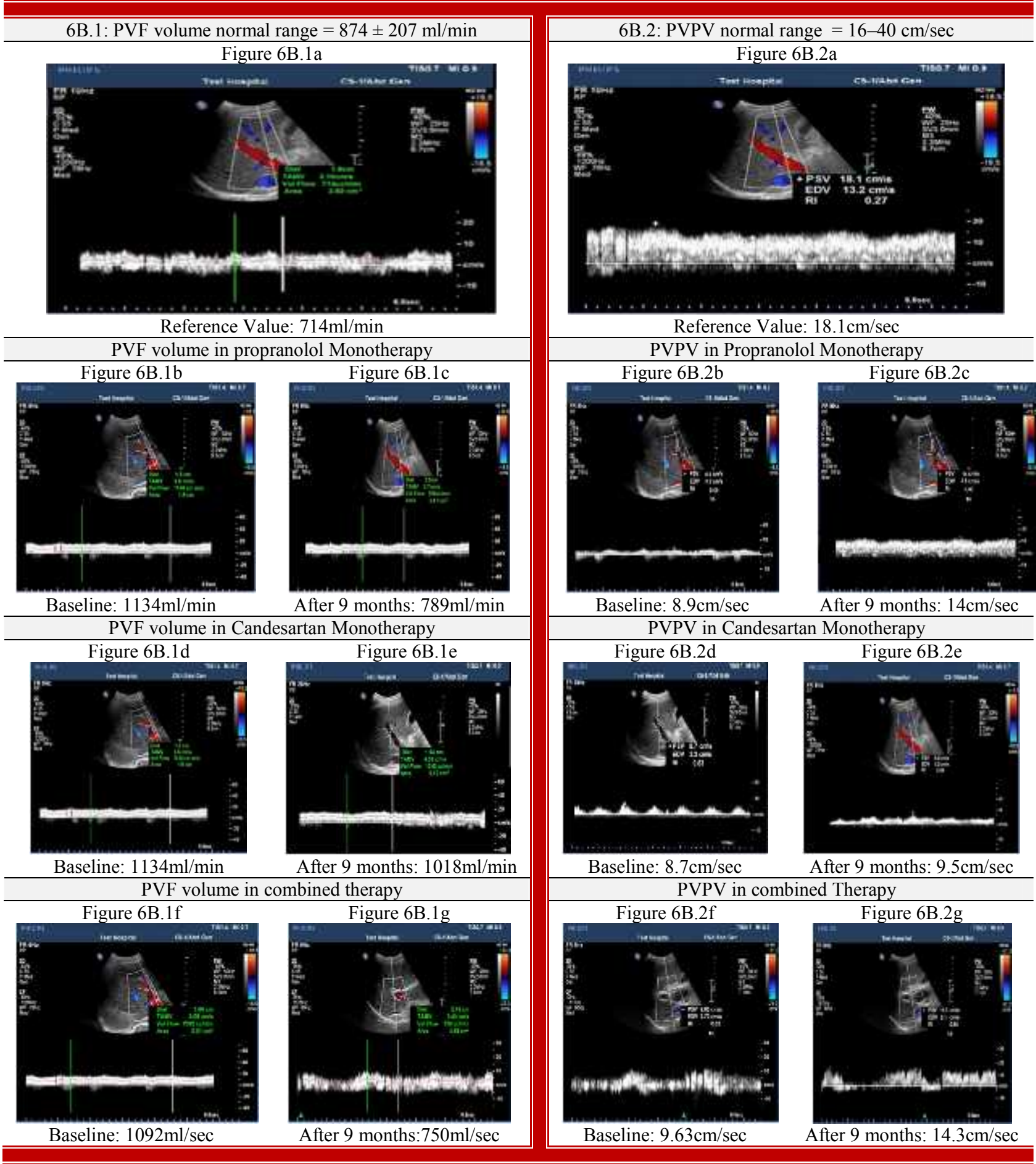

Restoration of PVF and PVPV normal wave patterns accomplished by combined therapy after nine month, Propranolol succeeded to restore PVPV normal wave pattern and VPF normal value at end of 9 month therapy. Candesartan monotherapy failed to restore normal pattern of PVF and PVPV at end of follow up. 


\section{Discussion}

Esophageal varices (OV) eradication by repeated ligation has been a practice of choice worldwide, as most of the endoscopists have preferred this procedure over sclerotherapy during the last three decades. OV ligation is used therapeutically in management of active OV bleeding, and prophylactically to prevent hematemesis from bending rupture OV. However, it seems that ligation and/or sclerotherapy of OV cuts off blood flow through visible channels, but didn't exclude opening new avenues that were obscured before ligation somewhere else. Risking a visible follow up tool like OV for the benefit of creating non-visualized collaterals or gastric varices (GV) wouldn't safe patient life, particularly when indications of OV ligation are questionable or even not clear. Current study proposes the use of medicines with new indications in controlling $\mathrm{PH}$ through reduction of Hepato-Portal vascular resistance and slowing down portal venous flow. Restoration of normal venous hemodynamic patterns in patient with $\mathrm{PH}$ would help to escape invasive OV management.

In the present study medical control of $\mathrm{PH}$ was crucial in prevention of growing and/or OV bleeding, but without effect on generation of new varices (Groszmann et al, 2005). NSBBs are indicated in management of $\mathrm{PH}$ as they produce attenuation of portal blood flow and vasoconstriction of splanchnic blood vessels (Bosch and Pagan, 2000). A mean reduction in portal pressure of $15 \%$ was reported by using NSBBs (Groszmann et al, 1990). Despite $15 \%$ of patients presented with hepatic cirrhosis were either hypersensitive to one of the NSBBs or unable to continue treatment; a significant hemodynamic response was observed in about $58 \%$ of them (Suk et al, 2007). The irreversible IHR changes are produced by extracellular matrix deposition in hepatic sinusoids, while the reversible dynamic ones result from sinusoidal contraction and twisting, and are induced by activated HSCs (Rockey, 1997;
Bosch and Pagan, 2000). Respectively, the former and the later are responsible for about $70-80 \%$ \& $20-30 \%$ of total IHR. Angiotensin II receptor antagonists alleviate the straining effect of Renin - angiotensin system on HSCs and are expected to minimize their role in pathogenesis of $\mathrm{PH}$ (Bataller et $a l, 2000)$. Monotherapy of $\mathrm{PH}$ with one of the ARBs (like Losartan and Irbesartan) was beneficial in some trials (Schneider et al, 1999; De et al, 2003) and ineffective with many side effects in other studies (Schepke et al, 2001; González-Abral-des et al, 2001).

The dose related side effects of ARBs (sever hypotension \& renal impairment) presented a major obstacle against using them as monotherapy in treatment of $\mathrm{PH}$. The present work was designed to use mono and combined therapy with small fixed dose of Candesartan (8 mg daily/patient) and/or adjusted dose of propranolol to control the hemodynamic sequelae of PH. For the first time, study subjects in each of the three groups were followed up every three month for a total of three follow-ups. Both synthetic and secretory functions of liver, kidney, and bone marrow were equally exposed to the same dose of ARB under almost the same conditions. The CBC as well as blood biochemistry (electrolytes in addition to renal and hepatic functions) showed no significant changes overtime among subjects of all groups. Candesartan, as mono or combined therapy, was well tolerated by all subjects who deemed to be thermodynamically safe even in cirrhotic liver with PH. Despite the significant changes in systemic blood pressure at the end of follow-Up compared to baseline; none of the studied patients suffered a severe hypotension that required elimination from current study. These findings are compatible with the reported ones in other studies (Markus et al, 2007; Kim et al, 2014). Portal circulation hemodynamic changes that involve DI, PI, HVF volume, and PVPV are induced by liver cirrhosis and probably the increased contractility of 
HSCs. In the present study, the above mentioned circulation indices (DI, PI, HVF volume, and PVPV) were reversed to normal value by combination therapy regimen (Propranolol plus Candesartan) at the end of the ninth month follow up. These overtime new beneficial findings that were reported for the first time by current study appear to falsely contradict what was reported in different studies, which reported that the addition of candesartan to propranolol did not show additional effect in the lowering of $\mathrm{PH}$. Their conclusion was based upon difficulties that included Candesartan dose adjustment and the side effects of its high doses (Markus et al, 2007; Kim et al, 2014). In fact, these studies that reported the effect of the same combined therapy on hemodynamic circulation in $\mathrm{PH}$, evaluated these changes only once after thee month (Markus et al, 2007; Kim et al, 2014). Their conclusions were totally compatible with current study results at a similar period of follow up (after the $1^{\text {st }}$ three month). However, the present study had two more follow ups at three month interval more than other studies, once after six month and the other after nine month. The reported restoration of normal values of DI, PI, PVF volume and PVPV had started to be gradually more obvious overtime in this work till all reached acceptable values within nine month.

The beneficial effects of ARBs on hepatic fibrosis were reported in both animal model and clinical trials (Kim et al, 2008; 2012). Candesartan was selected because of its potent highly selected long lasting action; it has a tight binging to and a slow releasing from AT1-Rs that led to strong angiotensin antagonism activities (Ojima et al, 1997; McClellan and Goa 1998; Burnier and Brunner, 2000). The data agreed with Kim et al. (2014) regarding need of large doses of candesartan as a monotherapy to yield the required anti-fibrotic and anti-PH activities over short time. But, its side effect on kidneys and systemic blood pressure present major obstacles against its use in large dose particularly over long time. Administration of small dose of Candesartan plus NSBBs over longer periods of time (more than 3 month) seemed to be effectively diminished contractility of HSCs as well as slowing down portal blood flow compared to monotherapy with either Candesartan or Propranolol. The overall activities of combined therapy including reduction of intrahepatic resistance and hepatic fibrosis associated with restoration of normal hemodynamic circulation functional capacity. The use of small dose of ARBs in combination with adjusted dose of NSBBs had the advantage of maintaining both systemic blood pressure and kidney function within normal values over study time in association with steady control of PH. The improvement in PV hemodynamics would be related to: a) the absorbed ARBs and NSBBs from GIT flooded both splanchnic organs and portal tract before escaping to systemic circulation $b$ ) the overtime saturation of AT1-R antagonism actions in splanchnic organs c) the prolonged inhibition of HSCs straining activities. These three factors play an overtime major role in slowing down portal venous blood flow and in reduction of IHR. This outcome could be produced by both synergistic effects between NSBBs \& ARBs in combined therapy and prolonged duration of medicine administration over nine month. Others attributed failure of combination therapy use for only 3 month to none optimum small doses of ARBs (Kim et al, 2014), which did not agree with the present study. The current study has several limitations. The most important ones are: a) fixation of ARB dose to investigate the effect of combination therapy and to use a small dose to ARB to avoid side effects in cirrhotic patients who are already hypotensive most of time, b) termination of follow up at nine month, which weaned from further changes in portal circulation hemodynamics despite stability in systemic blood pressure, c) Inability to evaluate the OV grading changes that were induced by the overtime effects of 
medical control (none invasive) of hypertensive PV hemodynamics; an interesting research point that has been planned to study separately, d) depending upon combination of chronic HCV infection, PV hypertensive hemodynamic parameters and Grade II - III OV without risk signs at baseline as inclusion criteria without measuring HVPG because of: 1) avoiding vascular invasive procedure was an absolute demand of participant 2) the preference was to measure sequelae and outcome of $\mathrm{PH}$ at baseline to be able to evaluate their overtime changes

\section{Conclusion}

Combined therapy of candesartan (ARB) and Propranolol (NSBB) showed significant improvement in DI, PI, PVF volume and PVPV after nine month. Response rate was better than either alone. ARB additional therapy to NSBB proved effective within traditional clinical dose and administration method.

\section{Acknowledgment}

Sincere appreciations to the Faculties of Medicine, Al-Azhar University and AlZagazig University, and to Hhia Central Hospital at Ministry of Health and Population for financial support.

Deep thanks to Prof. M. Bastawy, Prof. R. Mansour, Prof. A. Al-Zahaby, Prof. S. Elibiary, Prof. S. Rozeik, and Prof. A. Al Shety for their input in the manuscript revision.

\section{References}

Aoki, Hasumi, Hashizutne, M, et al, 1995: Hemodynamics analysis of findings in patients with portal hypertension: multicenter analysis in Japan: Japan portal hypertension study group. Hepatogastroenterol. 42, 6:1030-8.

Ballet, F, Chretien, Y, Rey, C, Poupon, R, 1988: Differential response of normal and cirrhotic liver to vasoactive agents: A study in the isolated perfused rat liver. J. Pharmacol. Exp. Ther. 244:283-9.

Barakat, M, 2002: Portal vein pulsatility and spectral width changes in patients with portal hypertension: relation to the severity of liver disease. Br. J. Radiol. 75:417-21.

Bataller, R, Ginès, P, Nicolás, JM, Görbig, MN, Garcia, E, et al, 2000: Angiotensin II in- duces contraction and proliferation of human hepatic stellate cells. Gastroenterology 118: 1149-56.

Bosch, J, García-Pagán, JC, 2000: Complications of cirrhosis. I. Portal hypertension. J. Hepatol. 32:141-56.

Burnier, M, Brunner, HR, 2000: Angiotensin II receptor antagonists. Lancet 355:637-45.

Dagradi, AE, 1973: Esophageal varices, splenic pulp pressure and directional flow patterns in alcoholic liver cirrhosis. Am. J. Gastroenterol. 59, 1:15-8.

D'Amico, G, de Franchis, R, Torri, V, 1999: Multicenter Italian Group: End-of-the-century reappraisal of the 6-week outcome of upper gastrointestinal bleeding in cirrhosis: A prospective study. J. Hepatol. 30:86-9.

D'Amico, G, Garcia-Tsao, G, Cales, P, Escorsell, A, Nevens, F, et al, 2001: Diagnosis of portal hypertension: how and when. In: de Franchis R, editor. Portal Hypertension III; Proc. $3^{\text {rd }}$ Baveno Int. Consensus Workshop on Def. Method. Therap. Stra. Oxford, UK: Blackwell Science.

Dauzat, M, Dubois, A, Aainteluce, P, et al, 1999: Explanation of hepatoportal circulation by Doppler ultrasonography. Echorevue L'informatiom Ultrasonore.

De, BK, Bandyopadhyay, K, Das, TK, Das, D, Biswas, PK, et al, 2003: Portal pressure response to losartan compared with propranolol in patients with cirrhosis. Am. J. Gastroenterol. 98: 1371-6.

Dib, N, Oberti, F, Paul, C, 2006: Current management of the complications of portal hypertension: variceal bleeding and ascites. CMAJ 174:1433-43.

Feu, F, García-Pagán, JC, Bosch, J, Luca, A, Terés, J, et al, 1995: Relation between portal pressure response to pharmacotherapy and risk of recurrent variceal haemorrhage in patients with cirrhosis. Lancet 346:1056-9.

Florence Komurian-Pradel, A, Gla'ucia Paran-hos-Baccala,' A, et al, 2001: Quantitation of HCV RNA using real-time PCR and Fluorimetry. J. Virol. Meth. 95:111-9

Friedman, SL, 2000: Molecular regulation of hepatic fibrosis, an integrated cellular response to tissue injury. J. Biol. Chem. 275:2247-50.

González-Abraldes, J, Albillos, A, Bañares, R, Del Arbol, LR, Moitinho, E, et al, 2001: Randomized comparison of long-term losartan ver- 
sus propranolol in lowering portal pressure in cirrhosis. Gastroenterol. 121:382-8.

Gonzalez-Abraldes, J, Albillos, A, Banares, R, et al, 2001: Randomized comparison of longterm losartan versus propranolol in lowering portal pre-ssure in cirrhosis. Gastroenterology 121: 382-8.

Groszmann, RJ, Bosch, J, Grace, ND, Conn, HO, Garcia-Tsao, G, et al, 1900: Hemodynamic events in a prospective randomized trial of propranolol versus placebo in the prevention of a first variceal hemorrhage. Gastroenterol. 99: 1401-7.

Groszmann, RJ, Garcia-Tsao, G, Bosch, J, Grace, ND, et al, 2005: Beta-blockers to prevent gastroesophageal varices in patients with cirrhosis. N. Engl. J. Med. 353:2254-61.

Hong, WK, Kim, MY, Baik, SK, Shin, SY, Kim, JM, et al, 2013: The usefulness of noninvasive liver stiffness measurements in predicting clinically significant portal hypertension in cirrhotic patients: Korean data. Clin. Mol. Hepatol. 19:370-5.

Hu, JT, Yang, SS, Lai, YC, et al, 2003: Percentage of peak-to peak pulsatility of portal blood flow can predict right-sided congestive heart failure. World J. Gastroenterol. 9:1828-31.

Kawai, S, Yokosuka, O, Kanda, T, Imazeki, F, Maru, Y, et al, 1999: Quantification of hepatitis $\mathrm{C}$ virus by TaqMan PCR: comparison with HCV Amplicor Monitor assay. J. Med. Virol. 58:121-6.

Kim, JH, Kim, JM, Cho, YZ, Na, JH, Kim, HS, et al, 2014: Effects of candesartan and propra-nolol combination therapy vs. propranolol monotherapy in reducing portal hypertension. Clin. Mol. Hepatol. 20, 4:376-83

Kim, MY, Baik, SK, Park, DH, Jang, YO, Suk, KT, et al, 2008: Angiotensin receptor blockers are superior to angiotensin-converting enzyme inhibitors in the suppression of hepatic fibrosis in a bile duct-ligated rat model. J. Gastroenterol. 43: 889-96.

Kim, MY, Baik, SK, Park, DH, Lim, DW, Kim, JW, et al, 2007: Damping index of Doppler hepatic vein waveform to assess the severity of portal hypertension and response to propranolol in li-ver cirrhosis: a prospective nonrandomized study. Liver Int. 27, 8:1103-10.

Kim, MY, Baik, SK, Yea, CJ, Lee, IY, Kim, H $\mathbf{J}$, et al, 2009: Hepatic venous pressure gradient can predict the development of hepatocellular carcinoma and hyponatremia in decompensated alcoholic cirrhosis. Eur. J. Gastroenterol. Hepatol. 21: 1241-6.

Kim, MY, Cho, MY, Baik, SK, Park, HJ, Jeon, HK, et al, 2011: Histological subclassification of cirrhosis using the Laennec fibrosis scoring system correlates with clinical stage and grade of portal hypertension. J. Hepatol. 55: 1004-9.

Kim, MY, Cho, MY, Baik, SK, Jeong, PH, Suk, KT, et al, 2012a: Beneficial effects of candesartan, an angiotensin-blocking agent, on compensated alcoholic liver fibrosis, a randomized open-label controlled study. Liver Int. 32: 977-87.

Kim, MY, Suk, KT, Baik, SK, Kim, HA, Kim, YJ, et al, 2012b: Hepatic vein arrival time as assessed by contrast-enhanced ultrasonography is useful for the assessment of portal hypertension in compensated cirrhosis. Hepatology 56:1053-62

Kim, MY, Um, SH, Baik, SK, Seo, YS, Park, S Y, et al, 2013: Clinical features and outcomes of gastric variceal bleeding: retrospective Korean multicenter data. Clin. Mol. Hepatol. 19:3644.

Li, T, Yang, Z, 2005: Research progress of vasculopathy in portal hypertension. World J. Gastroenterol. 11:6079-84.

Markus, H, Heim, L, Jacob, CB, 2007: The angiotensin II receptor antagonist candesartan is not effective in reducing portal hypertension in patients with cirrhosis. Digestion 75: 122-3

McClellan, KJ, Goa, KL, 1998: Candesartan ci-lexetil: A review of its use in essential hypertens- ion. Drugs 56:847-69.

Moriyasu, F, Nishida, O, Ban, N, Nakamura, T, Sakai, M, et al, 1986: Congestion Index of the portal vein. Am. J. Roentgenol. 146:735-9.

Ojima, M, Inada, Y, Shibouta, Y, Wada, T, Sanada, T, et al, 1997: Candesartan (CV11974) dissociates slowly from the angiotensin AT1 receptor. Eur. J. Pharmacol. 319:137-46.

Ozaki, CF, Anderson JC, Liebermann, RP, et al, 1988: Duplex ultrasonography as a non-invasive technique for assessing portal haemodynamics. Am. J. Surg. 155:20-4.

Rector, WGJ, Hoefs, JC, Hossack, KF, et al, 1988: Hepatofugal portal flow in cirrhosis: observations on hepatic hemodynamics and nature of arterioportal communications. Hepatol. 8:1620.

Rengo, C, Brevetti, G, Sorrentino, G, et al, 1998: Portal vein pulsatility ratio provides a 
measure of right heart function in chronic heart failure. Ultrasound Med. Biol. 24:32732.

Robinson, KA, Middleton, WD, Al-Sukaiti, R, et al, 2009: Doppler sonography of portal hypertension. Ultrasound Quarterly 25, 1:3-13.

Rockey, D, 1997: The cellular pathogenesis of portal hypertension: stellate cell contractility, endothelin, and nitric oxide. Hepatology 25:2-5.

Schepke, M, Werner, E, Biecker, E, Schiedermaier, P, Heller, J, et al, 2001: Hemodynamic effects of the angiotensin II receptor antagonist irbesartan in patients with cirrhosis and portal hypertension. Gastroenterol. 121:389-95.

Schneider, AW, Kalk, JF, Klein, CP, 1999: Effect of losartan, an angiotensin II receptor antagonist, on portal pressure in cirrhosis. Hepatol. 29: 334-9.

Suk, KT, Kim, MY, Park, DH, Kim, KH, Jo, $\mathbf{K ~ W}$, et al, 2007: Effect of propranolol on portal pressure and systemic hemodynamics in patients with liver cirrhosis and portal hypertension: a prospective study. Gut Liver 1:159-64.

Swart, J, Sheth, S, 2007: Role of vascular ultrasound in the evaluation of liver disease; Ultrasound Clin. 2:355-75
Thakeb, F, Zakaria, MS, M. Hunter, M, 1988: A study of oesophagus by endoscopy \& radiology after sclerotherapy: Gastrointestinal endoscopy: an Egyptian view. El-Sona El-Mohamadia.

Turnes, J, Garcia-Pagan, JC, Abraldes, JG, Hernandez, M, Dell'Era, A, et al, 2006: Pharmacological reduction of portal pressure and long-term risk of first variceal bleeding in patients with cirrhosis. Am. J. Gastroenterol. 101: 506-12

Verheijen, I, Vanderheyden, PM, De Backer, JP, et al, 2002: Antagonist interaction with endogenous AT(1) receptors in human cells. Biochem. Pharmacol. 64:1207-14.

Weinreb, J, Kumari, S, Phillips, G, Pochaczevsky, R, 1982: Portal vein measurements by real-time sonography. Am. J. Roentgenol. 139, 3:497-9.

Yokohama, S, Yoneda, M, Haneda, M, Okamoto, S, Okada, M, et al, 2004: Therapeutic efficacy of an angiotensin II receptor antagonist in patients with nonalcoholic steato-hepatitis. Hepatology 40:1222-5. 